\title{
Controlling Tuta absoluta (Meyrick) by Selected Crude Plant Extracts in the Laboratory and in the Screen House
}

\author{
Matendo Rehema Esther ${ }^{1}$, Nonga Hezron Emmanuel ${ }^{2}$, Bakari Gaymary George ${ }^{2}$, Ndusha Nabintu Bintu ${ }^{1}$, \\ Mwatawala Maulid Walad ${ }^{3}$ and Maerere Amon Petro ${ }^{3}$ \\ 1. Faculty of Agriculture and Environmental Sciences, Université Evangélique en Afrique, P.O. Box 3323, Bukavu, Sud-Kivu, \\ Republic Democratic of Congo or 165 Cyangugu, Rwanda \\ 2. Department of Veterinary Medicine and Public Health, Sokoine University of Agriculture, P.O. Box 3021, Morogoro, Tanzania \\ 3. Department of Crop Science and Horticulture, Sokoine University of Agriculture, P.O. Box 3005, Morogoro, Tanzania
}

\begin{abstract}
Effects of Commiphora swynnertonii, Synadenium glaucescens and Allium sativum extracts on the tomato leaf miner, Tuta absoluta (Meyrick) were evaluated on the adults and in screen house conditions. The adult stage was involved with 30 adults that were reared in an insectarium, the experimental design was a completely randomized design (plant extracts from three plants species $\times$ three doses of $2 \%, 4 \%$ and $8 \%$ ). In the screen house, experimental dispositive was a completely randomized block design (two varieties of tomatoes $\times$ three plants extracts). Larval counts were performed after $0,1,2,3$ and $7 \mathrm{~d}$ of treatment, 40 tomato leaves (10 $\times 4$ replicates) were randomly taken from each treatment. The mean percentage mortality of adults was recorded daily for $5 \mathrm{~d}$. Results indicated that, each plant extract caused significant mortality to adults of $T$. absoluta after $5 \mathrm{~d}$ in comparison to the control. Leaf dipping against adult of T. absoluta proved to be the most effective for all plant extracts at 30\%-100\%. Commiphora resulted in the adults' mortality of $100 \%$. In the screen house Commiphora showed the high reduction of infestation for Tanya and Cal $\mathrm{J}$ varieties. Treatment with this plant extract resulted in the highest fruit yield and the lowest yield loss compared to all the plant extracts. C. swynnertonii extract is recommended into integrated pest management strategies for the control of T. absoluta.
\end{abstract}

Key words: Plant pesticide, insect control, tomato, Tuta absoluta.

\section{Introduction}

Tomato (Solanum lycopersicum L.) is one of the world's major vegetables. It is a good source of nutrients and some secondary metabolites like folate, potassium, vitamins $\mathrm{C}$ and $\mathrm{E}$, flavonoids, $\beta$-carotene and lycopene are essential for human health [1]. In Tanzania, among others vegetables crops, tomato production is higher with a total annual production estimation of $235,000 \mathrm{t}$ [2]. Survey results in Morogoro Region, show that under current management practices, the yields vary from $2.2 \mathrm{t} / \mathrm{ha}$ to $16.5 \mathrm{t} / \mathrm{ha}$ [3] which is below the world average of 27.5 t/ha [2]. Many constraints prevent farmers from

Corresponding author: Matendo Rehema Esther, junior lecturer, research fields: food science and nutrition, natural products and antimicrobial activity. achieving potential yield. Some constraint are abiotic stresses like salinity, drought, declining soil fertility, poor crop management etc. and on the other hand biotic stress like pests and diseases [4]. The tomato leaf miner Tuta absoluta (Meyrick) (Lepidoptera: Gelechiidae) is a pest that originates from South America and devastates tomato plants [5]. This pest has invaded in Tanzania [6]; there are no official records of this pest in Tanzania; but the main concern is that it can cause serious yield losses of $50 \%$ to $100 \%$ [7]. T. absoluta has become a major threat to the sustainability of the production. Its control is a challenge as it rapidly develops resistance towards conventional insecticides [8]. The presence of $T$. absoluta in Tanzania also affects the export trade as the productivity is reduced and the local price of tomato soars. In 2015, tomato prices in the country 
rose by $375 \%$ in just a month, resulting from the tomato leaf miner outbreak [9].

Chemical control has been the main method used against $T$. absoluta in South America, the low efficiency of the active ingredients against the insect was reported since the 1990s [10]. In Tanzania the use of pesticide to control pests is high, with different combination of pesticides probably because farmers assume that the only solution to pest problems is to spray more frequently and use different types of pesticides [11]. Furthermore the use of synthetic pesticides poses a threat to the environment and health of tomato consumers [12] and increases production costs [13]. Thus, there is need to look for alternative technique that will improve the yields while safeguarding the environment and human health. Some higher plants are known to have broad spectrum activity and exhibit antibacterial, antifungal and insecticidal properties under laboratory and field tests [8]. Further, while resistance development continues to be an issue for many synthetic pesticides, it is likely that resistance will develop more slowly to plant-based pesticides owing to the complex mixtures of constituents that characterize many plants [14].

Three plants namely Synadenium glaucescens, Commiphora swynnertonii and Allium sativum were tested. These plants have been used in Tanzania traditional medicine $[15,16]$. Previous findings show that these plants have a broad spectrum activity against common pathogen in human and animals [15, 16]. The exudates of $C$. swynnertonii have been used traditionally to cleanse bladder and kill insects such as ticks, lice, bed bugs and mange mite [16]. Garlic oil which is an oviposition deterrent, has been found to be highly toxic to eggs of Plutella xylostella [17, 18]. Stem branches and buds of $S$. glaucescens have insecticidal and repellant properties against aphids, grasshoppers and mosquitoes [19].

The overall objective of this study was the development of alternative method of plant extracts to use synthetics pesticides in controlling T. absoluta in tomatoes in Morogoro, Tanzania. Specifically,

- To determine the in vitro effectiveness of $C$. swynnertonii, S. glaucescens and A. sativum plant extracts against adults of T. absoluta;

- To assess the in vitro effective concentration of the plant extracts against adults of $T$. absoluta on adults;

- To determine the effectiveness of the plant extracts on the tomato leaf miner in the screen house.

The aim of this study was the screening of different medicinal plants at appropriate doses against $T$. absoluta under laboratory and screen house conditions.

\section{Materials and Methods}

The experiment was conducted at Sokoine University of Agriculture Morogoro, Tanzania located at $6.822^{\circ} \mathrm{S}$ and $37.661^{\circ} \mathrm{E}$. The experiment was conducted under laboratory from January 2016 to June 2016, in the screen house from June to September.

The laboratory work of preparation of plant extracts was done at the Department of Veterinary Medicine and Public Health, while rearing and monitoring of $T$. absoluta were conducted at the Horticulture Unit. Thirty adults $T$. absoluta were placed in boxes $(5 \mathrm{~cm} \times$ $10 \mathrm{~cm} \times 10 \mathrm{~cm}$ ). After 1, 2, 3, 4 and $5 \mathrm{~d}$ of exposure, $T$. absoluta adults were observed in each treatment to assess mortality.

Roots of S. glaucensens were collected from Gairo district in Morogoro Region, while bulbs of A. sativum were purchased from the Mawenzi market in Morogoro municipality. Extract of C. swynnertonii was obtained from Natural Product Laboratory in the Department of Veterinary Medicine and Public Health.

The design of the laboratory experiments consisted of a $3 \times 3$ factorial (plant extracts from three plant species $\times$ three plant doses of $2 \%, 4 \%$ and $8 \%$ ) arranged in a completely randomized block design with three replications. In these experiments a synthetic insecticide BELT flubendiamide was used as 
positive control. These insecticides belong to the chemical family of substituted phtahalic acid diamides that have a very broad lepidoptera spectrum. For the tomato leaf miner the preparation is done by mixing $10-15 \mathrm{~mL}$ in $100 \mathrm{~L}$ of water, whereas sterile distilled water (SDW) containing $0.1 \%$ Tween ${ }^{\circledR} 20$ was used as negative control. The insecticide was used following the manufacturer's recommendations. The plant parts that were used in the experiment included: root bark (S. glaucensens), resin (C. swynnertonii) and bulb (A. sativum). The plant materials were packed into polyethylene bags, transported to the laboratory within $24 \mathrm{~h}$ after collection. The plant materials were cleaned of debris using running tap water. The bark material was first peeled from root stumps and chopped into small pieces before sun drying. For A. sativum, preparation of powder was carried out according to method described by Mahmood [20]. After cleaning, the bulbs were aseptically cut into small pieces with a knife and then dried in the shade for $7 \mathrm{~d}$ at $32-35{ }^{\circ} \mathrm{C}$. The semi-dried pieces were then blended using pestle and mortar, and left to dry in the shade at room temperature for further $7 \mathrm{~d}$. The materials were thereafter finely powdered with the help of a mixer-grinder and then stored in airtight bags in a cool dry room until when they were used. The resin was just kept in airtight bottle in the fridge until when it was used.

Solvent extraction was carried out according to the method described by Parekh and Chanda [21] with some modification. Each elite plant powder (resin) was separately extracted in ethanol (99.8\%). Exactly $100 \mathrm{~g}$ of ground plant material was soaked in $500 \mathrm{~mL}$ of ethanol in a conical flask plugged with aluminium foil and kept for $72 \mathrm{~h}$ in a dark place at room temperature. The total yield for Commiphora resin was $90 \%$ while for Synadenium $20 \%$ and A. sativum $18 \%$. The extracts, were filtered with Whatman filter paper 1 and the filtrate was concentrated using a rotary evaporator until all the solvent was cleared. The extracts were weighed to determine the percentage of paste in the dry material and then were stored at $4{ }^{\circ} \mathrm{C}$ in airtight bottles until use. The serial dilution method was used to prepare the working solutions at the three different concentrations of $2 \%, 4 \%$ and $8 \%$. In the laboratory the experiment was performed on the adult of T. absoluta using $2 \%, 4 \%$ and $8 \%$ concentrations of each plant extract. To maintain turgor of the petiole of each leaf, they were wrapped in humid cotton wool. Petri-dishes were maintained at conditions of the insectariums at $24 \pm 2{ }^{\circ} \mathrm{C}$. The positive and negative control treatments were also included. Each treatment was replicated three times. The number of live and dead adults of each treatment as well as control was recorded daily for $5 \mathrm{~d}$.

\section{Bioassay under Screen House Conditions}

To evaluate the effect of the treatment on $T$. absoluta population, naturally infested tomato plants of the two varieties (Tanya and Cal J) were grown in a screen house at the Crop Museum (SUA). Plants of the two varieties Tanya and Cal J planted in separate rows were used. The screen house had not been sprayed with any pesticide. Pre-treatment larval count was carried out by sampling 40 leaves randomly taken from each plot as four replicates of 10 each. The three different plants extracts were applied at $4 \%$. Treatments were applied by spraying the extract solution on the plant to run-off, using a hand held sprayer. To minimize cross infestation the plants were sprayed in the morning since T. absoluta is a nocturna insect. The positive control treatments were sprayed with BELT at the concentration of $0.2 \mathrm{~mL} / \mathrm{L}$, while the negative control was sprayed with $0.1 \%$ Tween $\AA$ 20 in SDW.

Larval counts were performed after $0,1,2,3$ and 7 $\mathrm{d}$ of treatment, 40 tomato leaves $(10 \times 4$ replicates $)$ were randomly taken from each treatment. On each day, these 40 leaves were taken from the different treatments and brought to the laboratory for examination under a binocular microscope (Leica MZ 12.5). The number of larvae of T. absoluta present on 
the leaves was counted and recorded. In screen house, for both varieties the incidence was equal, thus destructive sampling was used to calculate the reduction of the infestation within the treatment. The percentages of infestation reduction were calculated according to Henderson and Tilton's equation [22] as follows:

$$
\text { Reduction } \%=1-(a / b \times c / d)
$$

whereas $a=$ population in treatment after spraying; $b$ $=$ population in treatment before spraying; $c=$ population in check untreated (control) before spraying; $d=$ population in check untreated after spraying.

Reduction percentages were calculated after 1, 2, 3 and $7 \mathrm{~d}$ after treatment for the larvae.

\subsection{Data Collection}

The yield of the tomato plants of the two varieties was assessed in term of number of fruits per plant, fruit size, marketable and non-marketable fruits. The number of fruits per plant was assessed by counting the fruits of all trusses for the different treatments. Fruits size was measured by weighing the fruits from each treatment using an electronic balance.

After harvesting, all tomato fruits were sorted and graded into marketable and non-marketable fruits and weighted separately on a balance. Marketable fruit yield constituted of only fresh, non-damaged fruits suitable for selling while non-marketable fruit yield was made up of fruits damaged by pests. The total fruit yield was the sum of weights of marketable and non-marketable fruits yields. Yield loss was calculated using the following formula:

$$
\text { Yield losses }=[\text { Non-marketable } /(\text { Marketable }+
$$$$
\text { Non-marketable) }] \times 100
$$

\subsection{Data Analysis}

Data collected were subjected to analysis of variance (ANOVA) using GenStat version 8.1, at a difference declared significance of 5\% level. In the laboratory the experiment was done in a triplicate, and two-way ANOVA was used with concentration (three levels) and plant extract (three levels) as source of variation. In the screen house, the experiment was done in quadruplicate using two-way ANOVA with plant extract and varieties as factors. Descriptive statistics (mean, standard error of mean and coefficient of variation) were generated using GenStat procedures. Multiple means comparison was done using Turkey GenStat tool at 5\% level of significance. The determination of the lethal dose 50 of each plant extract was done by probit regression dose-response analysis using MedCalc software version 17.6.

\section{Results}

\subsection{Effect of Plant Eextracts on the Mortality of Adults of T. absoluta}

Results on the effects of the treatments on the adult stage of $T$. absoluta under laboratory conditions are presented in Fig. 1. The results showed that mortality of $10 \%$ occurred in the negative group within the test durations. Adult's mortality level under the laboratory conditions was significantly different among the treatments. Commiphora extracts caused the highest mortality of T. absoluta adults. The mortality caused ranged from $75.5 \%$ on day 1 to about $94 \%$ on day 5 . Synadenium extract caused the 2nd highest mortality, while garlic extracts and the conventional insecticides caused comparable mortality of about $63 \%$ to $64 \%$. This was significantly higher than the mortality caused by the negative control.

Results of the dose-response of each plant extract at different concentrations on adult mortality's of $T$. absoluta are presented in Fig. 2. The three different plant extracts show their effectiveness in controlling $T$. absoluta at the adult stage.

\subsection{Bio-Efficacy of Pesticides against Larvae of T. absoluta on Two Tomato Varieties}

Two varieties of tomato namely $\mathrm{Cal} \mathbf{J}$ and Tanya 


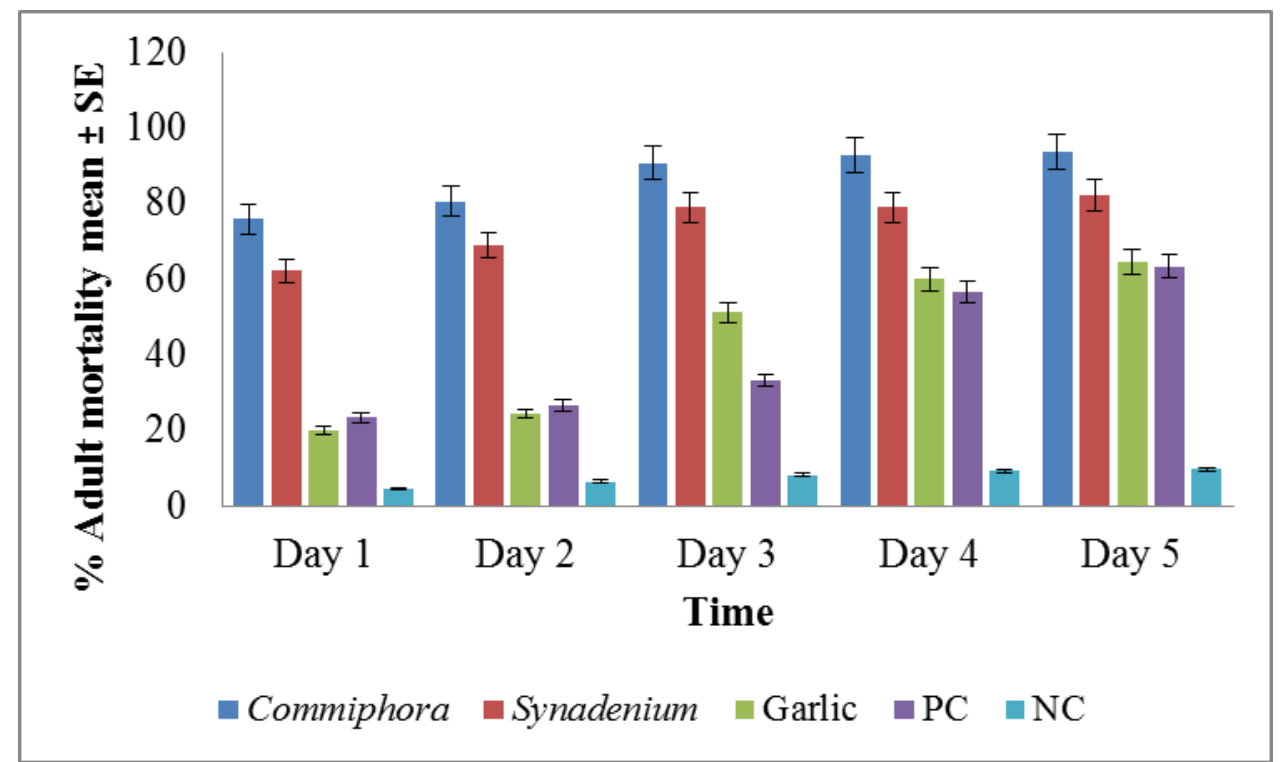

Fig. 1 Effect of plant extracts on the adult mortality of Tuta absoluta.

PC: positive control; NC: negative control.

were evaluated in this study to see the effectiveness of the plant extracts.

The results for variety $\mathrm{Cal} \mathrm{J}$ are presented in Table 1 and for Tanya in Table 2. The results show that reduction percentage of $T$. absoluta infestation on tomato leaves with the different tested plant extracts for the two varieties of tomatoes ranged between $19.3 \%-80.1 \%$ for Cal $\mathrm{J}$ and $22.7 \%-79.1 \%$ for Tanya after $7 \mathrm{~d}$ from application (Tables 1 and 2, respectively). There was no significant difference in the reduction of T. absoluta $(p>0.05)$ between the two varieties, while different plant extracts showed significant differences $(p<0.05)$. Generally, Commiphora was more effective at $80.1 \%$ for Cal $\mathrm{J}$ and $79.1 \%$ for Tanya in controlling T. absoluta than the positive control with $55.4 \%$ for Cal $\mathrm{J}$ and $54.2 \%$ for Tanya. Commiphora exhibited the highest effect on $T$. absoluta after $3 \mathrm{~d}$ followed by the positive control in both varieties. Synadenium showed the lowest reduction (22.7\% for Tanya and $19.3 \%$ for Cal J). In general, population of $T$. absoluta was significantly higher in negative treatment than other treatments. Under screen house conditions, the highest effects of the tested plant extracts against $T$. absoluta were observed after $3 \mathrm{~d}$ of treatment for Commiphora, when $87.7 \%$ and $89.1 \%$ on $\mathrm{Cal} \mathrm{J}$ and Tanya, respectively. The positive control caused reduction of $64 \%$ and $63.2 \%$ for Cal $\mathrm{J}$ and Tanya, respectively. On the 7th day the effect of the pesticide had decreased. The results are attributed to the fact that $T$. absoluta was more sensitive to some of the tested plant extracts after 2-3 d. Thereafter, the effect of the plant extract decreased and pest population increased.

\subsection{Effect of the Treatments on the Yield of Tomato}

Commiphora extract gave the highest yield of 1,200 $\mathrm{g}$ and $1,100 \mathrm{~g}$ for $\mathrm{Cal} \mathrm{J}$ and Tanya, respectively. Commiphora was followed by positive control and garlic (Fig. 3). There were no significant differences between the varieties. Negative control and Synadenium gave the lowest yield for both varieties. There were no significant differences between varieties and treatment on the total yield of the tomatoes. 


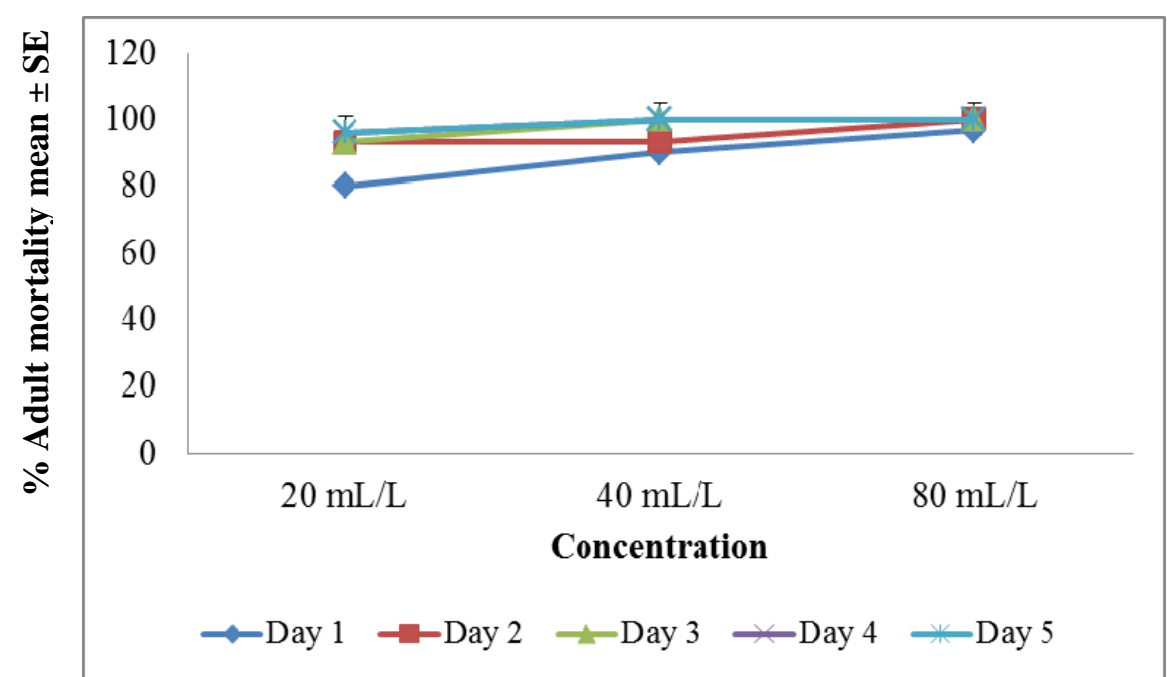

(a)

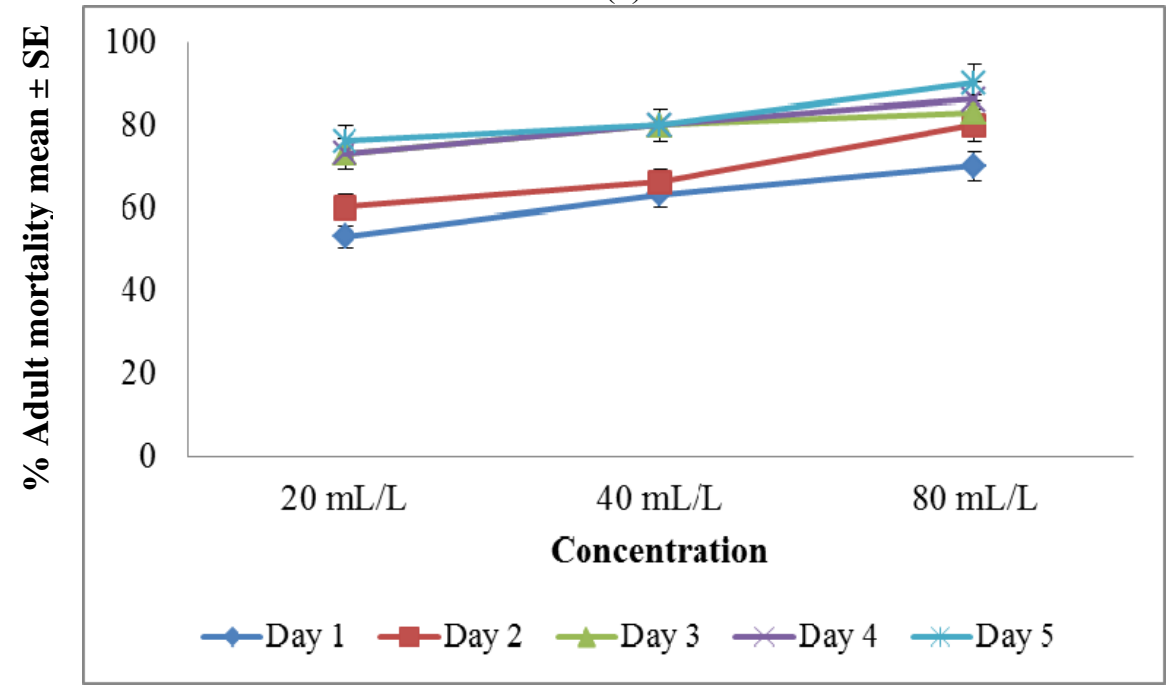

(b)

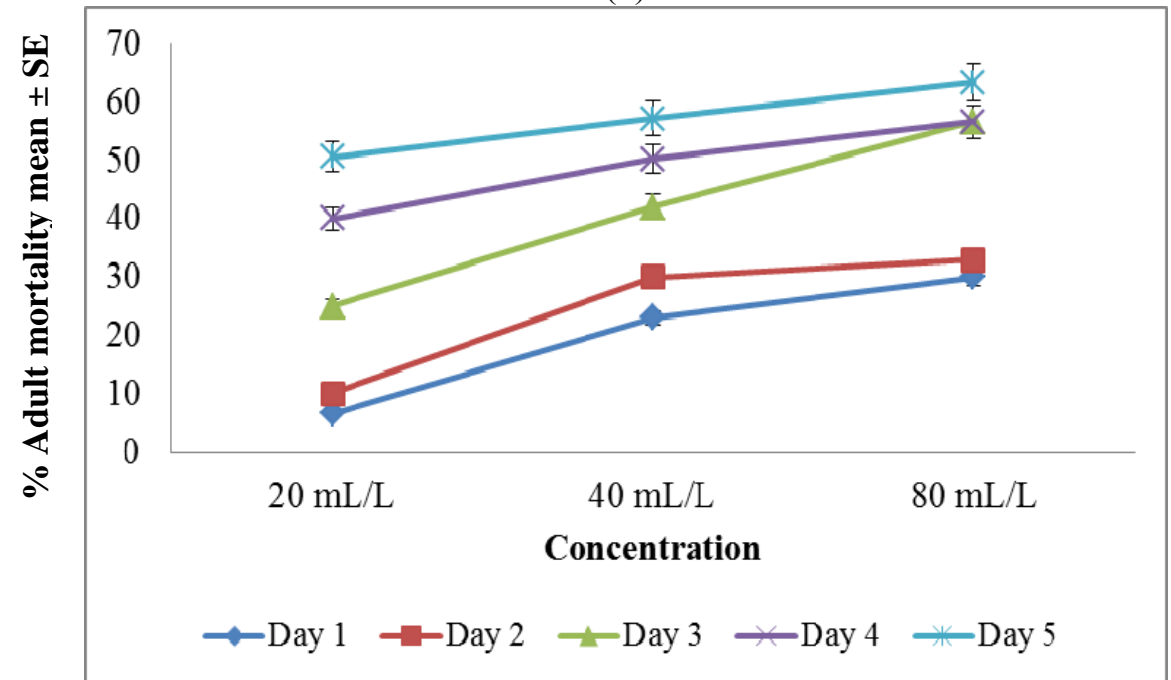

(c)

Fig. 2 Dose-response curve of each plant extract on adults mortality: (a) Commiphora; (b) Synadenium; (c) garlic. 

in the Laboratory and in the Screen House

Table 1 Effectiveness of the treatments on larvae of tomato leaf miner (Tuta absoluta (Meyrick)) on variety Cal $\mathbf{J}$ under screen house conditions.

\begin{tabular}{|c|c|c|c|c|c|c|c|c|c|}
\hline \multirow{2}{*}{ Plant extracts } & \multirow{2}{*}{ Pre-spray } & \multicolumn{4}{|c|}{ Average No. of surviving larvae } & \multicolumn{4}{|c|}{ Reduction percent $(\%)$} \\
\hline & & $1 \mathrm{~d}$ & $2 d$ & $3 d$ & $7 \mathrm{~d}$ & $1 \mathrm{~d}$ & $2 \mathrm{~d}$ & $3 \mathrm{~d}$ & $7 \mathrm{~d}$ \\
\hline Commiphora & 32 & 27 & 19 & 12 & 11 & $37.59 \mathrm{a}$ & $65.3 \mathrm{a}$ & $87.7 \mathrm{a}$ & $80.1 \mathrm{a}$ \\
\hline Synadenium & 29 & 30 & 27 & 32 & 35 & $4.6 c$ & $28.4 d$ & $26.8 \mathrm{~d}$ & $19.03 d$ \\
\hline Garlic & 35 & 27 & 28 & 15 & 23 & $24.3 b$ & $36.5 \mathrm{c}$ & $34 \mathrm{c}$ & $27.08 \mathrm{c}$ \\
\hline $\mathrm{PC}$ & 40 & 33 & 21 & 13 & 18 & $36.50 \mathrm{a}$ & $55.6 b$ & $64 b$ & $55.4 \mathrm{~b}$ \\
\hline $\mathrm{NC}$ & 31 & 34 & 38 & 43 & 47 & & & & \\
\hline$p$ & & & & & & 0.004 & 0.0003 & 0.001 & 0.001 \\
\hline $\mathrm{CV}$ & & & & & & 18.2 & 6.8 & 11.8 & 8.8 \\
\hline $\mathrm{SE} \pm$ & & & & & & 7.843 & 4.419 & 5.992 & 4.535 \\
\hline
\end{tabular}

Means followed by the same letter are not significantly different at $p<0.05$. PC: positive control; NC: negative control.

Table 2 Effectiveness of the treatments on larvae of tomato leaf miner (T. absoluta (Meyrick)) on variety Tanya under screen house conditions.

\begin{tabular}{|c|c|c|c|c|c|c|c|c|c|}
\hline \multirow{2}{*}{ Plant extracts } & \multirow{2}{*}{ Pre-spray } & \multicolumn{4}{|c|}{ Average No. of surviving larvae } & \multicolumn{4}{|c|}{ Reduction percent (\%) } \\
\hline & & $1 \mathrm{~d}$ & $2 \mathrm{~d}$ & $3 \mathrm{~d}$ & $7 \mathrm{~d}$ & $1 \mathrm{~d}$ & $2 \mathrm{~d}$ & $3 \mathrm{~d}$ & $7 \mathrm{~d}$ \\
\hline Commiphora & 25 & 25 & 14 & 9 & 8 & $34.6 \mathrm{a}$ & $65.9 \mathrm{a}$ & $89.4 \mathrm{a}$ & $79.1 \mathrm{a}$ \\
\hline Synadenium & 31 & 28 & 27 & 29 & 34 & $6.3 \mathrm{~d}$ & $23.7 \mathrm{~d}$ & $31.43 \mathrm{~d}$ & $22.7 \mathrm{~d}$ \\
\hline Garlic & 31 & 30 & 24 & 25 & 29 & $20.4 \mathrm{c}$ & $36.9 \mathrm{c}$ & $40.79 \mathrm{c}$ & $23.6 \mathrm{c}$ \\
\hline $\mathrm{PC}$ & 25 & 30 & 17 & 14 & 18 & $31.75 b$ & $48.9 b$ & $63.2 b$ & $54.2 b$ \\
\hline $\mathrm{NC}$ & 28 & 30 & 35 & 38 & 44 & & & & \\
\hline$p$ & & & & & & 0.001 & 0.0003 & 0.001 & 0.0002 \\
\hline $\mathrm{CV}$ & & & & & & 13.6 & 6.5 & 6 & 3.5 \\
\hline $\mathrm{SE} \pm$ & & & & & & 2.144 & 4.592 & 7.33 & 3.463 \\
\hline
\end{tabular}

Means followed by the same letter are not significantly different at $p<0.05$. PC: positive control; NC: negative control.

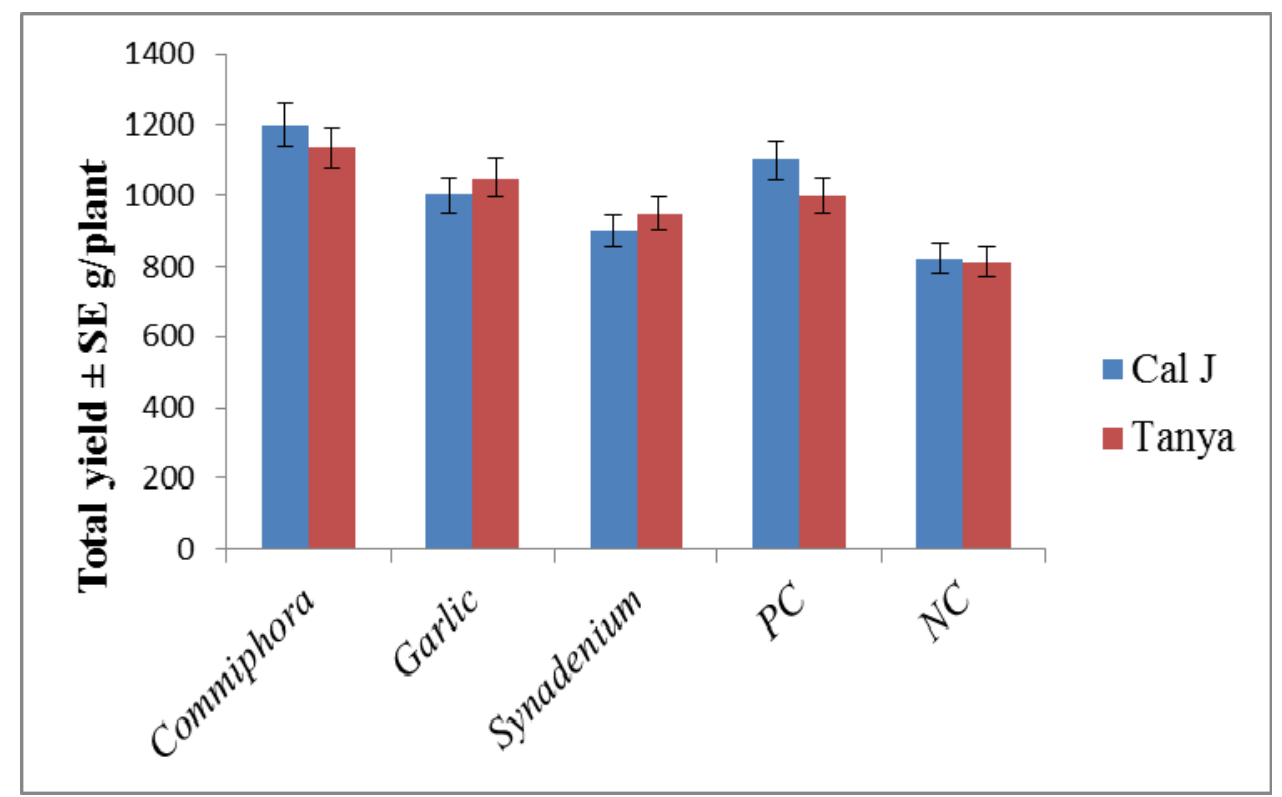

Fig. 3 Total yield of $\mathbf{C a l} \mathbf{J}$ and Tanya in different treatments.

PC: positive control; NC: negative control. 


\subsubsection{Yield in Number of Fruits per Plant}

There were no significant differences in number of fruits per plant between the two varieties (Cal J and Tanya) (Fig. 4). Results show that marketable and non-marketable fruit yields significantly differed $(p<$ 0.05) among plants extracts (Fig. 5). Commiphora and positive control had the highest number of marketable fruits. However, no significant differences were observed in number of marketable fruits between Synadenium, garlic and negative control. Neither there were no significant differences in number of non-marketable fruits between positive control, Synadenium and garlic.

4.3.2 Yield Loss of Different Varieties of Tomato

Results on tomato fruit weight losses are presented in Fig. 6. The treatments affected significantly the total loss. Commiphora extract led to the lowest percent of fruit yield loss with the extend of yield. The highest yield loss percent of $72.7 \%$ and $83.1 \%$ for $\mathrm{Cal}$ $\mathrm{J}$ and Tanya, respectively, which were recorded from the negative control treatment.

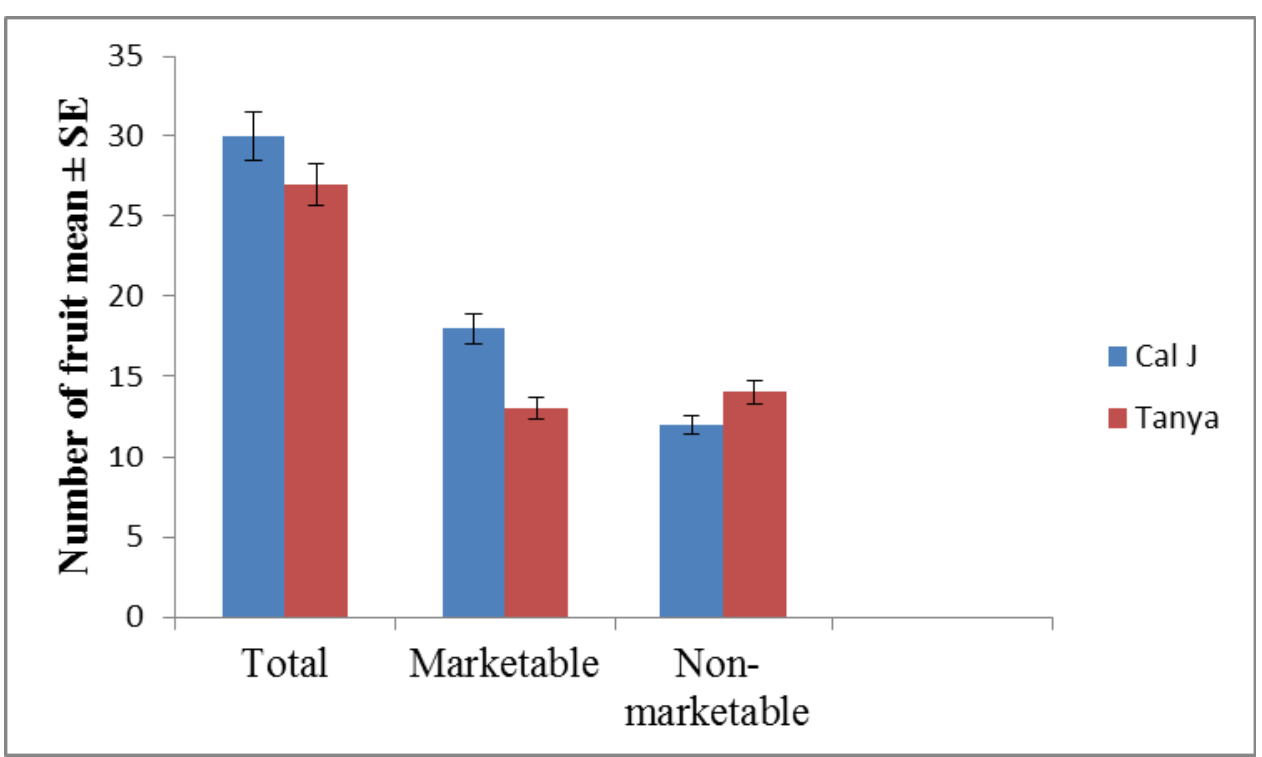

Fig. 4 Effect of varieties on the number of fruits.

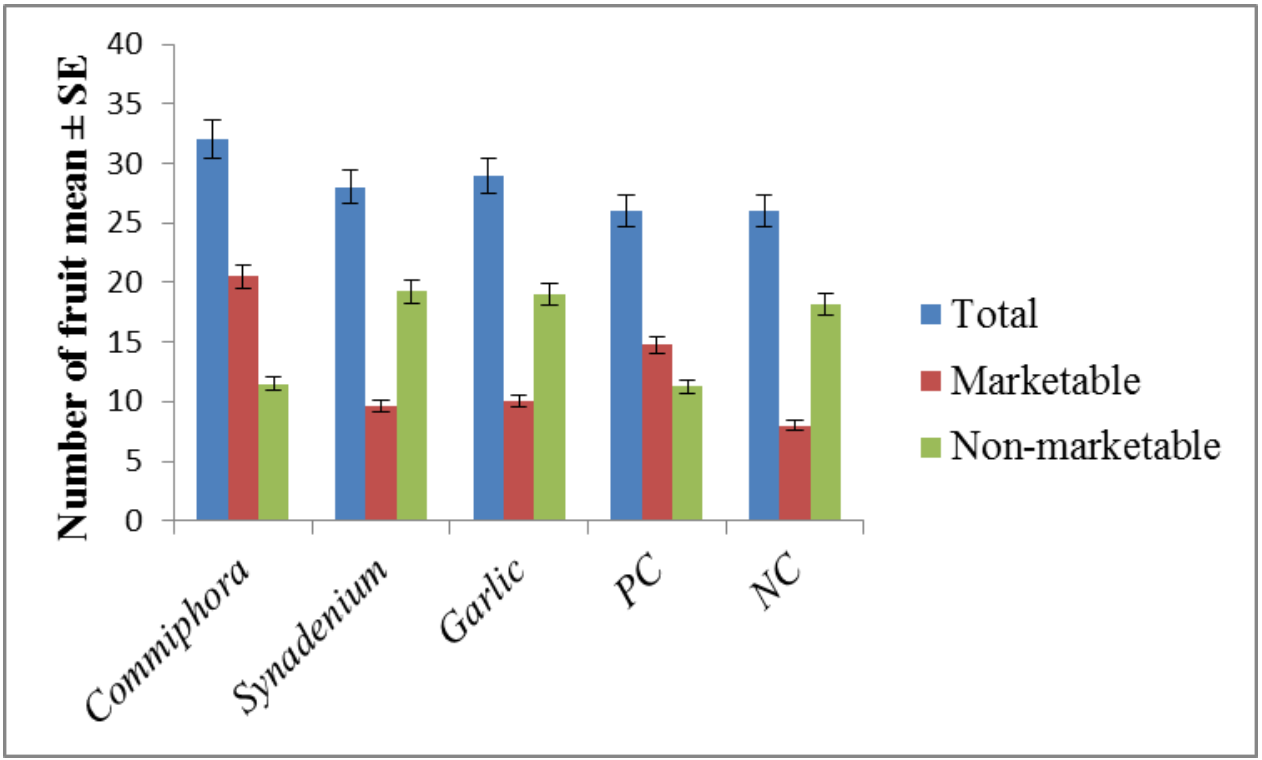

Fig. 5 Effect of different plant extracts on the number of fruit.

PC: positive control; NC: negative control. 


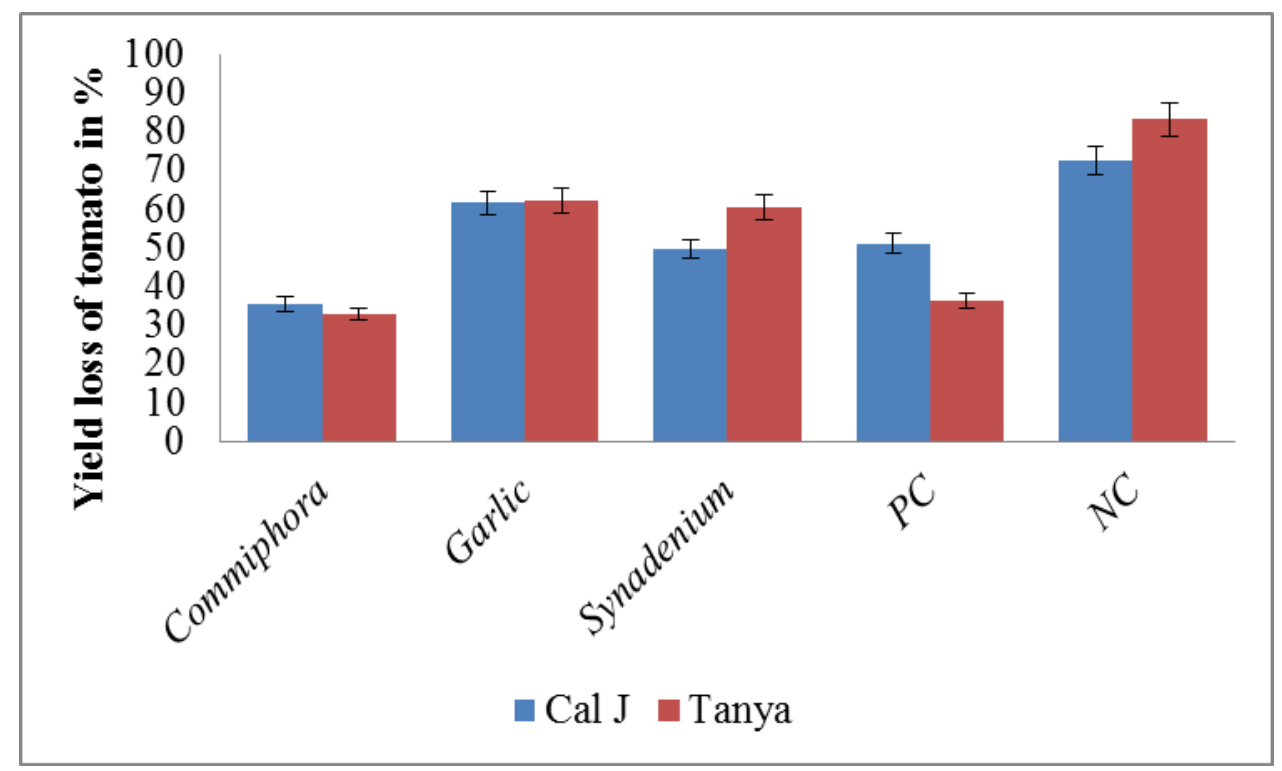

Fig. 6 Total yield loss of two varieties of tomato in different treatments.

PC: positive control; NC: negative control.

\section{Discussion}

All plant extracts caused mortality on the adult of $T$. absoluta, garlic extracts and the conventional insecticides caused comparable mortality of about $63 \%$ to $64 \%$ while the high mortality was recorded by Commiphora extract.

Many previous studies reported effective larval control of $T$. absoluta with botanical materials. Nadia et al. [23] reported that application of four concentrations of neem (Azadirachta indica) seeds ethanolic extract and Jatropha (Jatropha curcas) seeds petroleum ether extract on young larvae of $T$. absoluta resulted in larval mortalities that ranged between $33 \%-46.7 \%$ and $23.5 \%-48.5 \%$, respectively, obtained after $24 \mathrm{~h}$. Also, higher larval mortalities, up to $100 \%$, were obtained with the two extracts after $4 \mathrm{~d}$ of treatments. Moreno et al. [8] tested the bioactivity of hexane and ethanol extracts of 23 plants against $T$. absoluta larvae. Their results showed that, hexane extract of Acomella oleracea was the most active against T. absoluta larvae. Nilahyane et al. [24] applied extracts of seven plants against $T$. absoluta larvae; their results showed that, the extracts had varying levels of toxicity for the larvae. The most effective was that of Thymus vulgaris (95\%), followed by Ricinus communis (58\%). In a similar laboratory study, Ghanim and Abdel [25] used five plant extracts against 2 nd instars larvae of T. absoluta. Their results showed that, chinaberry caused the highest effects on T. absoluta larvae, followed by geranium, onion and garlic. Essential constituents of most of the plant extracts in this study are primarily lipophilic compounds that act as toxins, feeding deterrents and oviposition deterrents to a wide variety of pests. Insecticidal properties of several plant extracts to the housefly, red flour beetle and southern corn root-worm were reported [26]. Although many plant extracts have insecticidal properties, the degree of toxicity of different compounds to one species differs considerably.

Repeated modes of action of Azadirachtin included induced cessation in feeding (antifeeding) and growth inhibition [27-29]. Studies showed that they reduced moulting and caused deformations in pupae and decreased fecundity of females [30]. The antifeedant effects of azadirachtin are partly due to sensory detection and avoidance by insects [31].

The insecticidal activity of Commiphora exudate parallels other findings. For instance essential oils of Commiphora leaves repelled ticks and the repellence 
activity was associated with presence of sesquiterpenoids [18]. Also bark extracts induced mortality in nymphs and adults of Rhipicephalus appendiculatus ticks [32]. Insecticidal activity in the genus Commiphora is not unique to C. swynnertonii. There are other species with strong acaricidal activities including C. erythraea [33] and C. myrrh [34].

The effectiveness of the insecticidal activity of $C$. swynertonii exudates on T. absoluta was a function of their concentration as well as the duration of exposure to the exudates. At $8 \%$ concentration, more than 90 of adults died by day 2 . A lower concentration of $2 \%$ did not cause high mortality on day 1 and day 2 , but progressively the adults' mortality increased on day 3 and by day 5 more than $90 \%$ of adults had died. At a higher concentration (4\% and 8\%) 100\% mortality was realized on day 3. At a higher concentration the effect was immediate while at a lower concentration there was immediate action but the residual amounts on the adults continue to elicit the effect.

The present study shows that effect of plant extract decreased with time after treatment. So, the insect populations increased again as a result of the decrease of residual effects. Ghanim and Abdel [25] studied the effects of basil, geranium, chinaberry, onion and garlic aqueous extracts against T. absoluta (Meyrick) and the cotton aphid, Aphis gossypii (Glover). The authors reported the highest effect of the plant extracts after 4 d which also decreased with time. Decreased efficacy of plant extracts over time was previously attributed to activity of insects' secretion system [35]. Moreira et al. [36] associate differences in plant extracts toxicity with differential susceptibility of the insect.

In this study garlic had moderate effectiveness on the pest. However, Hussein et al. [37] showed a high reduction of $T$. absoluta population after tomato plants were treated with garlic extract. The moderate reduction of $T$. absoluta during this study was due to the extraction method that affects the presence of some volatile oil that confers to garlic its biological properties. Results of this study were however in agreement with those reported by Ghanim and Abdel [25], who showed effects of garlic on T. absoluta $2^{\text {nd }}$, instars larvae under laboratory conditions, but with moderate effects under greenhouse conditions. Also, garlic leaf lectin (ASAL) had detrimental effect on growth and survival of two important homopteran insect pests, Lypaphis erysimi, commonly known as aphids and Dysdercus cingulatus (red cotton bug) [38]. Neem, garlic and ginger extracts contain insecticidal properties that are lethal to a wide range of insects [39].

Garlic is a major source of sulphur containing compounds (alkyl sulfides) with different numbers of sulfur atom (i.e., mono-, di- and tri-sulfide). Volatile compounds such as allicin, diallyl disulphide, diallyl trisulphide (a major constituent of garlic oil), dithiins, and ajoene originate from different metabolic pathways by tissue damage through cutting, crushing or chewing. These compounds provide garlic with its characteristic odour and flavour as well as its biological and antifeeding properties [40]. Similar results with other pests were obtained by Panhwar [41] who reported that good aqueous solution of garlic would effectively control worms, beetles and thrips in cowpea.

Results obtained in this study are similar to those reported by Ahmed et al. [42] on cowpea and by Panhwar [41]. These authors showed that, plant extracts increased the yield of vegetables by protecting them from insect pests. According to Gaby [43], plant extracts application at flowering and pod formation stages reduced the level of infestation of insect pests and increased yield of pea plants.

T. absoluta reduced yield and fruit quality grown under green house and open field conditions. Severely attacked tomato fruits lose their commercial value. Losses ranging from 50\%-100\% have been reported on tomato [44]. Damage is directly related to the reduction of plants' photosynthetic capacity and of production levels in both protected and open field. 
Indirect damage to the tomato crop can also be caused by secondary infection by pathogens developing on the infested plants and fruits tissues [45]. As larvae are internal feeders it is difficult to achieve an effective control through application of chemical insecticides. Moreover, T. absoluta can rapidly evolve into strains with reduced susceptibility to insecticides that have been previously effective.

Results obtained by Hussein et al. [37] indicated that controlling $T$. absoluta by essential oil significantly affected fresh weight, shape index, total soluble solids, thickness of pericarp, $\mathrm{pH}$ and ascorbic acid. Interestingly, the tested plant extracts and essential oils affected the percentage of dry weight of fruits and vegetative growth of tomato plants significantly. Also, the lemon grass and garlic plant extracts and most of the essential aromatic oils (eucalyptus, rue, anise, basil) increased the total yield of tomato.

Results reported by Tyagi et al. [46] revealed that plant growth improved and plant weights also increased with increasing concentration of leaf lemon grass extract and with longer dip duration.

\section{Conclusions}

Based on the findings of this study, it is concluded that all plant extracts were effective and controlled adult T. absoluta. Commiphora extracts were highly effective and controlled T. absoluta in screen house. Foliar application reduced T. absoluta population, improved quality and yield of tomato. This bio-insecticide can be integrated in pest management program and organic farming.

\section{Recommendations}

Based on the finding of the present study, the followings are recommended:

Isolation and the screening of the bioactive compound against different strain of T. absoluta.

Since Commiphora exhibited a good activity in vitro and in the screen house, it should be subjected in open field application to see its effectiveness. Since only one part of the each plant was used further studies should be carried out in order to study different parts of the same plant and extracted by different solvents to compare their effectiveness. It is recommended to do further studies on molecular characterization of $T$. absoluta insect for understanding different strains circulating in Tanzania. Therefore, further studies should be carried out to integrate Commiphora with other integrated or biological control methods in order to reduce the use of chemicals and, consequently, improve food safety and environment quality.

\section{Acknowledgment}

The authors are grateful to the Université Evangélique en Afrique and INTRA-ACP mobility project for the financial support granted to me in form of scholarship.

\section{References}

[1] Tehniat, S., Ijaz, A., Shahnaz, C., Muhammad, K. S., and Muhammad, N. K. 2014. "DPPH Free Radical Scavenging Activity of Tomato, Cherry Tomato and Watermelon: Lycopene Extraction, Purification and Quantification." Academic Sciences International Journal of Pharmacy and Pharmaceutical Sciences 6 (2): 223-8.

[2] Food and Agriculture Organization (FAO). 2012. Growing Greener Cities in Africa First Status in Peri-Urban Horticulture in Africa. Rome, Italy: Food and Agriculture the United Nations, 58.

[3] Maerere, A. P., Sibuga, K. P., Mwajombe, K. K., Bulali, J., William, M., Mwinyipende, L., Mbwambo, J., and Shayo, J. 2006. Baseline Survey Report of Tomato Production in Mvomero District, Morogoro Region, Tanzania. Regional Integrated Pest Management Program for East Africa: Kenya, Tanzania and Uganda, unpublished, 21.

[4] Ojiewo, C. O., Swai, I. S., Oluoch, M. O., Silué, D., Nono-Womdim, R., Hanson, P., Black, L., and Wang, T. C. 2010. "Development and Release of Late Blight-Resistant Tomato Varieties 'Meru' and 'Kiboko'." International Journal of Vegetable Science 16: 134-47.

[5] Miranda, M. M., Picanco, M., Zanuncio, J. C., and Guedes, R. N. C. 1998. "Ecological Life Table of Tuta absoluta (Meyrick) (Lepidoptera: Gelechiidae)." Biocontrol Science Technology 8: 597-606. 
[6] Chidege, M., Al-zaidi, S., Hassan, N., Julie, A., Kaaya, E., and Mrogoro, S. 2016. "First Record of Tomato Leaf Miner Tuta absoluta (Meyrick) (Lepidoptera: Gelechiidae) in Tanzania." Agriculture and Food Security 5: 17.

[7] Giulianotti, L. G. 2010. "Certis IPM Programme for the Control of Tuta absoluta." Int Pest Control 52: 162-5.

[8] Maneno, C., Secilia, M., and Christopher, L. M. 2015. "Knowledge and Practices of Agricultural Extension Officers in Management of the Invasive Tuta absoluta Meyerick (Gelechiidae) in Tanzania." International Journal of Science and Research 5 (5): 428-30.

[9] Moreno, S. C., Carvalho, G. A., Picanc, M. C., Morais, E. G. F., and Mpereir, R. E. 2011. "Bioactivity of Compounds from Acmellaoleracea against Tuta absoluta (Meyrick) (Lepidoptera: Gelechiidae) and Selectivity to Two Non-target Species.” Pest Management Science 68: 389-93.

[10] Campos, M. R., Rodrigues, A. R. S., Silva, W. M., Silva, T. B. M., Silva, V. R. F., Guedes, R. N. C., and Siqueira, H. A. A. 2014. "Spinosad and the Tomato Borer Tuta absoluta: A Bio-Insecticide, an Invasive Pest Threat, and High Insecticide Resistance." Journal of Economic Entomology 80: 210-28.

[11] Ngowi, A. V. F., Mbise, T. J., Ijani, A. S. M., London, L., and Ajayi, O. C. 2007. "Pesticides Use by Smallholder Farmers in Vegetable Production in Northern Tanzania." Crop Protection 26 (11): 1617-24.

[12] Mtui, H. D., Maerere, A. P., Bennett, M. A., and Sibuga, K. P. 2015. "Effect of Mulch and Different Fungicide Spray Regimes on Yield of Tomato (Solanum lycopersicum L.) in Tanzania." African Journal of Food, Agriculture, Nutrition and Development 15 (1): 9607-19.

[13] Reis, A., Ribeiro, F. H. S., Maffia, L. A., and Mizubuti, E. S. G. 2005. "Sensitivity of Brazilian Isolates of Phytophthora infestans to Commonly Used Fungicides in Tomato and Potato Crops.” Plant Disease 89: 1279-84.

[14] Koul, O, Walia, S., and Dhaliwal, G. S. 2008. "Essential Oils as Green Pesticides: Potential and Constraints." Biopesticides International 4: 63-84.

[15] Bakari, G. G., Max, R. A., Mdegela, R. H., Phiri, E. C., and Mtambo, M. M. 2011. "Antibacterial and Antifungal Activities of Commiphora swynnertonii (Burt) against Selected Pathogens of Public Health Importance." Research Journal of Biological Sciences 6 (4): 175-9.

[16] Mabiki, F. P., Mdegela, R. H., Mosha, R. D., and Magadula, J. J. 2013. "In Ovo Antiviral Activity of Synadenium glaucescens (Pax) Crude Extracts on Newcastle Disease Virus.” Journal of Medicinal Plants Research 7 (14): 863-70.

[17] Lanzotii, V. 2006. "The Analysis of Onion and Garlic." Journal of Chromatography A 1112: 3-22.

[18] Kaonekane, B., Mollel, M., and Lyatu, F. 2007. "Leaf
Essential Oil Composition and Tick Repellency Activity of Commiphora swynnertonii Burt." Journal of Biology Resources Thessaloniki 8: 213-6.

[19] Grainge, M., and Ashmed, S. 1988. Handbook of Plants with Pest Control Properties. New York: Journal Wiley and Sons, 238-48.

[20] Mahmood, M. A. 2009. "Efficacy of Crude Extracts of Garlic (Allium sativum Linn.) against Nosocomial Escherichia coli, Staphylococcus aureus, Streptococcus pneumoniea and Pseudomonas aeruginosa." Journal of Medicinal Plants Research 3 (4): 179-85.

[21] Parekh, J., and Chanda, S. 2007. "Antibacterial and Phytochemical Studies on Twelve Species of Indian Medicinal Plants." African Journal of Biomedical Research 10: 175-81.

[22] Henderson, C. F., and Tilton, E. W. 1955. "Tests with Acaricides against Brown Wheat Mite." Journal of Economic Entomology 48: 157-61.

[23] Nadia, E. M. K., Awad, K. T., and Mohammed, E. E. M. 2014. "Effects of Botanical Extracts of Neem (Azadirachta indica) and Jatropha (Jatropha curcus) on Eggs and Larvae of Tomato Leaf Miner, Tuta absoluta (Meyrick) (Lepidoptera: Gelechiidae).” Persian Gulf Crop Protection 3 (3): 41-6.

[24] Nilahyane, A., Bouharroud, R., Hormatallah, A., and Taadaouit, N. A. 2012. "Larvicidal Effect of Plant Extracts on Tuta absoluta (Lepidoptera: Gelechiidae)." IOBC-WRPS Bulletin 80: 305-10.

[25] Ghanim, N. M., and Abdel, G. S. 2014. "Controlling Tuta absoluta (Lepidoptera: Gelechiidae) and Aphis gossypii (Hemiptera: Aphididae) by Aqueous Plant Extracts." Life Science Journal 11 (3): 299-307.

[26] Rice, P. J., and Coats, J. R. 1994. "Insecticidal Properties of Several Monoterpenoids to the Housefly (Diptera: Muscidae), Red Flour Beetle (Coleoptera: Tenebrionidae) and Southern Corn Root-Worm (Coleoptera: Chrysomelidae).” J. Economic Entomology 87: 1172-9.

[27] McMillian, W. W., Bowman, M. C., Starks, K. J., and Wiseman, B. R. 1969. "Extract of Chinaberry Leaf as a Feeding Deterrent and Growth Retardant for Larvae of the Corn Earworm and Fall Armyworm." Journal of Economy and Entomology 62: 708-10.

[28] Meisner, J., Ascher, K. R. S., Aly, R., and Warhben, J. D. J. 1981. "Response of Spodoptera littoralis (Boisd.) and Earias insulata (Boisd.) Larvae to Azadirachtin and Salannin.” Phytoparasitica 9: 27-32.

[29] Raffa, K. F. 1987. "Influence of Host Plant on Deterrence by Azadirachtin of Feeding by Fall Armyworm Larvae (Lepidoptera: Noctuidae)." Journal of Economic Entomology 80: 384-7.

[30] Isman, M. B., and Machial, C. M. 2006. "Pesticides Based on Plant Essential Oils: From Traditional on 

in the Laboratory and in the Screen House

Lepidopterous Larvae and Their Feeding Response. Natural Pesticides from the Neem Tree (Azadirachta indica A. Juss) and Other Tropical Plants." In Proceedings of the 2nd International Neem. Conference, edited by Schmutter, H., and Asher, K. R. S. Germany: German Agency for Technical Cooperation, 57.

[31] Simmonds, M. S. J., and Blaney, W. M. 1984. "Some Neurophysiological Effects of Azadirachtin on Lepidopterous Larvae and Their Feeding Response.” In Natural Pesticides from the Neem Tree and Other Tropical Plants, edited by Schmutterer, H., and Ascher, K. R. S. GTZ, Eschborn, Germany, 163-80.

[32] Kaonekane, B., and Mollel, M. 2012. "Acaricidal Activities of Extracts of Commiphora swynnertonii Burt (Burseraceae), Melia volkensii Gurke, Turraea abyssinica Hotchst, Turraea floribunda Hochst and Turraea cornucopia Styles and F. White (Meliaceae) against the Brown Ear Tick Rhipicephalus appendiculatus Neumann.” Journal of Open University of Tanzania 10: 25-34.

[33] Carrol, J. F., Maradufu, A., and Warthen, J. D. 1989. “An Extract of Commiphora erythraea, a Repellant and Toxicant against Ticks." Entomologia Experimentalis and Applicata 53: 111-6.

[34] Maradufu, A. 1982. "Furanosesquiterpenoids of Commiphora erythraea and C. myrrh." Phytochemistry 21: 677-80.

[35] Sarmamy, A., Hashim, H., and Sulayman, A. 2011. "Insecticidal Effects of Some Aqueous Plant Extracts on the Control of Khapra Trogoderma granarium Evert." In International Conference on Chemical, Biological and Environment Sciences (ICCEBS 2011), Bangkok, 288-92.

[36] Moreira, M. D., Picanco, M. C., Barbosa, L. C., Guedes, R. N. C., and Da Silva, E. M. 2004. "Toxicity of Leaf Extracts of Ageratum conyzoides to Lepidoptera Pests of Horticultural Crops." Biological Agriculture and Horticulture 22: 251-60.

[37] Hussein, N. M., Hussein, M. I., Gadel, S. H., and Hammad, M. A. 2014. "Effect of Two Plant Extracts and Four Aromatic Oils on Tuta absoluta Population and
Productivity of Tomato Cultivar Gold Stone." Nature and Science 12 (7): 108-18.

[38] Bandyopadhyay, S., Roy, A., and Das, S. 2001. "Binding of Garlic (Allium sativum) Leaf Lectin to the Gut Receptors of Homopteran Pests Is Correlated to Its Insecticidal Activity." Plant Science 161 (5): 1025-33.

[39] Oparaeke, A. M. 2007. "Toxicity and Spraying Schedules of a Bio-Pesticide Prepared from Piper guineense against Two Cowpea Pests." Plant Protection Sciences 43: 103-8.

[40] Ben, I. C., Nudubuisi, U., and Maxwell, N. B. 2010. "Comparative Studies on Effects of Garlic (Allium sativum) and Ginger (Zingiber officinale) Extracts on Cowpea Insects Pest Attack." World Rural Observations 2 (2): 34-44.

[41] Panhwar, S. B. 2002. "Farmers' Adoption of Plant Materials for Insects' Control." International Service for National Agricultural Research 4: 61-8.

[42] Ahmed, B. I., Onu, I., and Mudi, L. 2009. "Field Bio-Efficacy of Plant Extracts for the Control of Post Flowering Insect Pests of Cowpea (Vigna unguiculata (L.) Walp.) in Nigeria." Journal of Biopesticides 2 (1): 37-43.

[43] Gaby, S. 2000. Natural Crop Protection in the Tropics, 2nd ed. Weikersheim, Germany: Margraf Verlag Press, 502.

[44] European and Mediterranean Plant Protection Organization (EPPO). 2005. "Tuta absoluta. Data Sheets on Quarantine Pests." EPPO Reporting Service 35: 434-5.

[45] European and Mediterranean Plant Protection Organization (EPPO). 2012. "Biology Distribution and Damage of Tuta absoluta an Exotic Invasive Pest from South America." In Proceedings of Symposium on Management of Tuta absoluta, Agadir, Morocco, November 16-18, 2011, 33.

[46] Tyagi, S. A., Ahmad, A., and Alam, M. M. 1990. "Control of Root-Knot, Reniform and Stunt Nematodes by Root Dip in Leaf Extract of Lemon Grass." International Pest Control 32 (3): 68-71. 